\title{
Grounding the Theory of Discursive Resistance: Language, Semiotics and New Testament Theology
}

\author{
Timo Juhani Eskola
}

check for updates

Citation: Eskola, Timo Juhani. 2021. Grounding the Theory of Discursive Resistance: Language, Semiotics and New Testament Theology. Religions 12: 776. https://doi.org/10.3390/ rel12090776

Academic Editors: Joel B. Green and John Jillions

Received: 6 July 2021

Accepted: 14 September 2021

Published: 16 September 2021

Publisher's Note: MDPI stays neutral with regard to jurisdictional claims in published maps and institutional affiliations.

Copyright: (C) 2021 by the author. Licensee MDPI, Basel, Switzerland. This article is an open access article distributed under the terms and conditions of the Creative Commons Attribution (CC BY) license (https:/ / creativecommons.org/licenses/by/ $4.0 /)$.
Department of Biblical Studies, Theological Institute of Finland, 00100 Helsinki, Finland; timo.eskola@sti.fi

\begin{abstract}
Focusing on semantics and semiotics, this article will suggest new and renewed approaches to studying the construction of New Testament theology. First, the relation between Saussure and Peirce will be analyzed because the interpretation of their relationship is crucial for understanding the process of signification. A critical stance will be taken towards Derrida and Eco's interpretation of signification and towards deconstruction. Applying Benveniste's development of Saussure's semantics will introduce a discursive theory. Linguistic signs are not simply linguistic units as such. A sign is about conditions and functions. A sign as a role is a manifestation of participation. For anything to serve as a sign entails participation in a web of relations, participation in a network of meanings, and adoption of a set of rules. In the act of encoding there are elements that resist the free selection of components in encoding, such as narratives and metaphors. Therefore, they also become a means of appropriation: the construction of the sentence is not spontaneous but constrained. When, for instance, the metanarrative of enthronement directs the construction of a Christological statement, the basic theme dominates the process and becomes compelling for the ancient author.
\end{abstract}

Keywords: New Testament theology; semiotics; semantics; metanarrative; signification; discursive resistance

\section{Introduction}

Semiotics, while gaining only periodic popularity and only among rather specialized scholars is, nevertheless, the main explanative factor behind most of the recent trends in New Testament interpretation. In the U.S., Jacques Derrida's influence has been immense, as evidenced by the numerous different projects proposing deconstruction. On the continent, the legacy of Ferdinand de Saussure has been remarkable despite the fact that later interpretations have never reached unanimous conclusions about his work. And, last but not least, C.S. Peirce has had an exceptional impact on the theory of meaning all over the globe. As we take an interest in semiotics, we must and need commit ourselves to serious work on many fundamental issues concerning the nature of language.

Furthermore, there are several myths circulating in scholarly circles that need thorough reconsideration. It is a commonplace to read in a textbook, for instance, that Saussure's conception of the sign is dyadic, while Peirce's conception is triadic. Everyone knows Derrida's claim that his theory of language is based on Saussure's conception of langue. Umberto Eco, in turn, claims in his main treatment $A$ Theory of Semiotics that the classic semantic triangle by Ogden and Richards can be paralleled with Peirce's famous triad. It is essential to question each and every one of these statements.

Why is this necessary? All these misunderstandings have produced high profile interpretative theories which have spread widely, for instance in deconstruction and a/theology, postmodern theologies, negative theology, death-of-God, as well as progressive theology. The basic problem here is that if the first premises turn out to be defective, their applications need to be reconsidered. The main aim of this essay is to analyze the use of the concept of sign and to apply a coherent Saussurean interpretation of signification to the study of New Testament theology. I will first investigate the complex history of the theory of signification because it is impossible to understand the nature of present theories 
without knowing their premises. Then, in Section 6, I will argue for a new theoretical approach, that of discursive resistance, based on the theories of Saussure and Benveniste in particular. The validity of this interpretation will be put to the test by concentrating on some particular biblical passages focused especially on the themes of jubilee and liberation.

\section{Saussure vs. Peirce: Dyadic or Triadic Conception of the Sign?}

One must start with the definition of the linguistic sign. This, simple as it seems, is a complex task. Contemporary philosophy, ever since Immanuel Kant, has mainly been philosophy of language. Frege the linguist and logician sent Wittgenstein to Cambridge, and Heidegger searched for authentic language most of his career. Therefore, it is rather surprising that the linguistic turn that Saussure engendered had so little impact on philosophy and theories of signification. Should we conclude that philosophy of language was not actually interested in language?

Starting with Saussure today is not commonplace. He has been exploited in so many ways that it is in fact hard to explore the basic tenets of his linguistic thinking. Most scholars of course recognize his concepts signifiant (signifier) and signifié (signified) but after that, debates arise. Is Saussure's conception of the linguistic sign dyadic as so many writers assume? It certainly appears to be, but does this mean that his theory of signification was dyadic? In semiotical literature, Saussure's theory is often contrasted with Peirce's theory of semiosis, which is triadic. Or is it? Is Peirce really discussing the linguistic sign here? Admittedly, the task is huge and in what follows it is possible only to present certain crucial arguments on which a consistent hermeneutical theory can be constructed. A more thorough investigation of the theory needs to be conducted elsewhere (Eskola 2021).

Saussure's concept of the sign is not precisely dyadic. It is bipartite (de Saussure 1983, p. 66). This is an important distinction. The bipartite understanding of the sign as such is the basis for the revolution. For Saussure, the signifier or "sound pattern," as he calls it, is just a mental image of a sound pattern. The original French expression is "image acoustique," an acoustic image. It is a mental entity that lives in our minds. It is something that remains only in our memory. In a sense it is an engram (Sebeok 2001, 5f.; Tobin 1990, p. 39).

Together these elements construct a linguistic sign and these signs, in turn, compose a formal language system (langue). One can see one practical example of such a system in a dictionary. Meanings in a dictionary are not (solely) dependent on etymology but, instead, on the synchronic language system that is spoken for instance in any given country today. This is why Finnish-English dictionaries, for instance, grow old so quickly. The main issue in Saussure's theory is that words, in this sense, are concepts. They are general concepts denoting species and classes. They form a code, not a nomenclature where each "word" provides a "name" (nominatio) for some particular in the real world.

Meaning, therefore, is not simply dictated by the system. Langue provides merely the system of signs that can be used in encoding. Saussure spoke of parole but, unfortunately, never got to explain that aspect of language in his lectures. He assumed that it was not a topic for linguists to handle. At least so we are told. Émile Benveniste developed the idea later and introduced the term utterance meaning. Saussure focused on the proper nature of langue, the linguistic system, to prove that nominalism with its theory of primitive reference had been completely wrong.

It is important to emphasize that Saussure's conception of the linguistic sign is bipartite. This distinction is crucial. His understanding of practical meaning is a matter of parole, and the process of signification presupposes encoding. This makes his theory of signification triadic. This means that which interests us the most is not simply a matter of a dictionary's definitions. Particular, contextual meaning proper is not a matter of the code as such. It is a matter of using language. It is a matter of encoding, a matter of utterance.

In Peirce's thinking, signs are always involved in triadic relations. This is the basic point of departure in his epistemology. All signs as representamens have a relation to their objects and to an interpretative element, the interpretant. Meaning, therefore, is practical and is constructed by creating new interpretants in a thinking process. This, however, is 
not simply a picture of the linguistic meaning-and this is where the most problematic mistakes are made.

Linguistic signs are not defined in terms of triadic relations. As Peirce investigates the categories of different signs, he presents the linguistic sign in his second trichotomy.

"[S]econdly, according as the relation of the sign to its object consists

in the sign's having some character in itself, or

in some existential relation to that object, or

in its relation to an interpretant." (CP 2.243)

Peirce's second trichotomy is referential, and introduces his most famous distinction between icon, index, and symbol. He explicates here the relation of signs to their objects in the real world. The first mode concerns quality. The class of performance speaks of existential relation. And third, that of thought, brings in the role of the interpretant. Each of these can later be used in the triadic relations. Our interest lies in the third group. Words in Peirce's semiotics belong to the category of Symbol. In fact, this can also address an entire linguistic system.

Word, for Peirce, is a sign because a law of language - a convention-makes the interpreter connect a symbol with the object it denotes (Greenlee 1973, p. 94; Pharies 1985, p. 41). Since words are conventional, their meaning is based on a law. But what kind of signs are words, since they belong only to one class of aspects on the second level of Peirce's triadic categories? Why can these signs not be defined by all three levels? The reason is simple: words are elements of semiosis. They are not the results of semiosis.

Peirce is a realist in the sense that he still speaks of real objects. There is, however, an important distinction that affects his theory, that between an immediate object and a dynamical object. The object in his theory means two quite different things. He still believes in the referential object as his examples of e.g., icon and index prove. In addition to this, Peirce also calls representation an object.

"We have to distinguish the Immediate Object, which is the Object as the Sign itself represents it, and whose being is thus dependent upon the Representation of it in the Sign, from the Dynamical Object, which is the Reality which by some means contrives to determine the Sign to its Representation." (CP 4.563)

As regards the linguistic sign, the immediate object corresponds to the conventional sign, which is a general concept. Pharies notes that the immediate object "corresponds perfectly to Saussure's 'signifié' in being an idea or concept whose very being depends, as Saussure agrees, on the clarifying power of the sign which designates it." (Pharies 1985, p. 15) One should, however, remember that not all of Peirce's immediate objects are general concepts of the conventional language system. Peirce could also address all representations, representamens, belonging to the processes of semiosis. So the question is more complicated. An immediate object can be any idea produced during a thinking process. Here the meanings in question greatly surpass the lexical meanings of individual words. This notion is useful since in his semiotics Peirce distinguishes between lexical meanings and more complex concepts quite like Saussure did (Hervey 1982, p. 36).

When Peirce explains how signs are related to information, he simultaneously addresses the issue of lexical meanings and denotations. He calls denotation and connotation (meaning respectively reference and sense), somewhat unorthodoxly, breadth and depth: "the dyadic relations of logical breadth and depth, often called denotation and connotation, have played a great part in logical discussion". These, however, have often been discussed in a flawed context because, "these take their origin in the triadic relation between sign, its object and its interpretant sign". The dyadic explanation "forgets that concepts grow" (CP 3.608). Liszka explains the difference as follows (Liszka 1996, p. 28):

"The essential depth of a sign is all the qualities or characteristics that are predicated of it simply by means of its definition, or general, conventional understanding (CP 2.410). The essential breadth, on the other hand, is all those things to which, 
according to its very meaning, the sign refers. The term 'human being' has a dictionary meaning, and refers to whatever satisfies that definition in a vague and general way. Peirce claims that the essential depth and breadth of a sign do not really give us information in the strict sense of the term, but instead a sort of 'verbal knowledge' (MS 664:20)."

When defining the lexical meaning of a word, Peirce goes even beyond Saussure when he states that depth (connotation) as a general concept is determined by all qualities and characteristics that have been or can be predicated of it. Definitions have many dimensions, and symbols/linguistic signs have a vast range. Accordingly, the breadth of a linguistic sign (denotation; reference) covers all possible objects that can be referred to only if the qualities or characteristics allow the application.

Furthermore, Peirce's "Saussurean" distinction between langue and parole is confirmed here. He clearly speaks of a linguistic system as a collection of lexical meanings, "dictionary meanings" as he says (sense). Standard linguistic systems before Peirce had been dyadic, as he notes. The use of linguistic signs, however, belongs to the field where "triadic relations" work. Signification proper, denotation in the scheme mentioned above, which falls in the category of breadth, are in the world of semiosis. This explains how concepts grow and, in accordance with what Peirce says about interpretants, through semiosis a "translation" takes place and "the meaning of a sign is the sign it has to be translated into" (CP 4.132). Liszka notes that Peirce "defines information as the quantity of the interpretant," and as such, information "is a dimension of meaning achieved in the systematic intersection (or the area) of the sign's breadth and depth (CP 2.419)" (Liszka 1996, p. 29).

Considering similarities between Saussure and Peirce, the result is surprising. Even in their different contexts they both speak of a bipartite linguistic sign. For Saussure this was a linguistic innovation and for Peirce a philosophical necessity. They both believed that meaning proper is a matter of using language. It is a matter of creating ideas and constructing utterances. Furthermore, they were convinced that a nominalistic alternative was impossible. No nominatio could explain the proper meaning of propositions. This conclusion will be of utmost importance as we turn to Derrida and the post-structuralist reading of both Saussure and Peirce.

\section{Derrida, Différance and Deconstruction}

Derrida's importance stems from his claim to have learned both from Saussure and Peirce. He does not recognize the distinction between langue and parole but maintains that language is merely a self-referential system of signs where words refer only to other words. There is a logical reason for such a conclusion. Derrida was a radical phenomenologist. He developed many of his ideas in his dissertation on Husserl. His philosophy can be understood only when remembering that he deals with phenomena and the cognitive handling of these phenomena. Derrida is known for his two major concepts: différance and deconstruction. The former is an epistemological concept. Derrida created a neologism, derived from the French verb différer, meaning deferring and moving forward. The French suffix "-ance" makes the word a noun. Therefore, for Derrida, this neologism expresses constant deferring (Derrida 1982, 3f.). But what does this mean?

For Derrida any intuition in one's mind is merely a trace of Being (real reality). He states that the Being of beings "can never be presented." Neither can there be an actual manifestation of the trace, because it will appear only through différance, always escaping other manifestations and deferring meaning in the linguistic system. A quotation explains this best (Derrida 1982, p. 23).

"As rigorously as possible we must permit to appear/disappear the trace of what exceeds the truth of Being. The trace (of that) which can never be presented, the trace which itself can never be presented: that is, appear and manifest itself, as such, in its phenomenon. The trace beyond that which profoundly links fundamental ontology and phenomenology. Always differing and deferring, the trace is never as it is in the presentation of itself. It erases itself in presenting 
itself, muffles itself in resonating, like the $a$ writing itself, inscribing its pyramid in différance."

An appearance produces a trace in our minds, and this trace keeps escaping the reality of the occurrence. For Derrida, interpretation is a process where reality cannot be present and cannot become manifest as such. What is left are interpretations which are treated by the mind. These interpretations are further organized with the help of a system of signs. The trace will be represented by a sign which in itself is already part of another system. Derrida never discusses the genesis of words in the linguistic system.

The crucial point in this discussion is that none of Derrida's terms can be understood properly without his third concept: noema. Intentional acts of consciousness have a structure of meaning, a noematic structure, or simply a noema, as Derrida calls it. When a mental act is directed at an object, for instance at a book or at a computer, the mode of directedness is always constructed by a noema. Or, to keep it simple, a noema is being constructed every time a mental act is directed at an object. As a result, each different noema has a "meaning" by which it is linked to the object. So it is not the object itself which directs meaning, but the way the object manifests itself as a phenomenon. Therefore, the structure of meaning is constantly changing, since it depends on the changing manifestation (Derrida 1973, p. 19). Contrasting Saussure, he states: "there is neither symbol nor sign but a becoming-sign of the symbol." (Derrida 1997, p. 47).

For Derrida, therefore, there are two complementary movements, différance and noema. These movements prove that language and words have nothing to do with reality. For Derrida, observation is nothing but a play between phenomena and intuition. The mind works on impressions and uses the only system that it has available - the linguistic system. This is why Derrida adopted Saussure's theory of langue, that of a linguistic system. As a system of general concepts it is self-referential and must be considered a closed system as such. No representation selected from this repository of codes can represent anything else but impressions, according to Derrida. People do not speak about reality but about language.

\section{Derrida and Eco: Reinstating the Primitive Reference Theory}

Derrida's view is rather extreme. Under certain conditions such a view might grow into a garden of death where all meaning perishes. And so it has. Scholars speak of a real deconstruction industry where all semantic values are considered dead, and deconstruction is a tool for dissemination and destruction. In philosophy moral values were scrutinized according to deconstruction, and, in theology, all this grew into the theory of the death-ofGod. G-o-d has been treated as a sign that needs to be erased. Epistemology of darkness results in a theology of no-thingness (Raschke 1979, p. 8). Assuming that Derrida was right, that is.

There are severe problems in Derrida's theory, though. His greatest mistake is that, despite speaking so highly of Saussure, Derrida adopts an old view of primitive reference and thus places himself among Saussure's opponents. Like so many philosophers before him, Derrida is not really interested in language. The pertinent two questions, repeated throughout his essay are, what is a linguistic sign? How is meaning constructed? When Derrida and later his follower Eco attempt to explain the theory of meaning, they wish to unite the Peircean triadic approach and the nominalist theory of referential meaning. Hence they run into problems when trying to apply Saussure's ideas to their own theory.

In his Of Grammatology, Derrida compares the patterns of Saussure and Peirce. He adopts some of Saussure's terminology, speaking for instance about signifiers and signifieds, but eventually he supports Peirce's approach. The reason for this is that, according to Derrida, it is Peirce who in his theory of semiotics dissolved the close relation between signifier and signified. Hence, for Derrida, Peirce became a forerunner for the idea of differánce. By proposing a semantic interpretation of Peirce's semiotics, Derrida claims that the relation between signifier and signified is unstable. A crucial conclusion follows: in this discussion the interpretant must be understood as the conceptual content of sign. 
Derrida assumes that, according to Peirce, the referent of the sign is indefinite. "Now Peirce considers the indefiniteness of reference as the criterion that allows us to recognize that we are indeed dealing with a system of signs." (Derrida 1997, p. 48).

To assess this solution we will concentrate on Eco who, in his A Theory of Semiotics (Eco 1976), presents an interpretation where the theory of semiosis appears built on a similar tension. Eco presents his Derridean interpretation in diagrams where he compares and parallels Peirce's views with several well-known semantic patterns. This is where triads enter the stage. Firstly, Eco refers to Ogden and Richards, who presented a pattern of signification in a triadic form (Eco 1976, 59f.; Ogden and Richards 1966, p. 11).

\section{REFERENCE \\ $\triangle$ REFERENT}

Ogden and Richards' triad changes the Fregean pattern (see below) only slightly and focuses on the meaning of individual words. Furthermore, it can be applied to any symbol, explaining the production of meaning. A symbol is now linked with a concept, actually called the reference here. In addition to this it also has an object, a referent, to which it refers. Naturally such a referent may be either a factual, existing thing or merely a concept.

This semantic triad is then considered identical with Peirce's triadic pattern of semiosis. In order to emphasize this, Eco presents Peirce's pattern in a similar diagram.

\section{INTERPRETANT}

\section{REPRESENTAMEN OBJECT}

Echoes of Derrida are obvious, but this comparison reveals many inconsistencies in Eco's interpretation. In Peirce's theory the representamen is the bipartite sign itself. The object is then the referent that is being described. Eco distorts Peirce's original idea with this new identification where the interpretant becomes the conceptual content of the sign, i.e., "the signified" in Saussurean terminology. Thus he gives the pattern of semiosis a (nominalist) semantic interpretation. This line of thought is further emphasized by a comparison with Frege's classical (German) pattern of signification. The interpretation is underscored by using a triangular pattern and drawing an actual triangle.

\section{SINN \\ $\triangle$ \\ ZEICHEN BEDEUTUNG}

Frege's so-called triad has clearly influenced Ogden and Richards' diagram above. There is no doubt that Frege did make a distinction between intension and extension. The conceptual meaning of a sign (word), Sinn, is here the lexical meaning (intension) which is designated in the linguistic system as having merely general meanings. The referential meaning, Bedeutung, brings the object into the picture. This is why Frege remains in the nominalist tradition. Now Eco drew parallels between these three patterns, emphasizing that in all these diagrams the left side, i.e., the relation between sign and concept, can be seen as identical with Saussure's dyadic view of a sign. He even stated that the relation was similar to "the Saussurean dichotomy 'signifiant—signifié"'. This, however, is not what Saussure meant. In fact, he claimed the opposite.

Based on such comparisons, Eco further stated that Peirce's and Saussure's diagrams are actually similar. He assumed that neither of them paid much attention to the actual object of reference (Eco 1976, p. 60).

"The semiotics of Saussure and Peirce is a theory of the conventional (or at any rate strictly semiosical) relation between symbol and reference (or meaning) and between a sign and the series of its interpretants [...] Objects are not considered within Saussure's linguistics and are considered within Peirce's theoretical framework only when discussing particular types of signs such as icons and indices [...]." 
This comparison reveals the mistake. By following Derrida, Eco falls into the standard nominalist referential theory of meaning with both a reinterpreted Saussurean "triad" and Peirce's concept of semiosis. Considering his solution in the light of philosophy, however, there is no triad here. Eco merely presents a "fork." Like in Abelard's theory, words have now a direct reference. This is why Eco actually reinstates the primitive reference theory where nominatio and significatio are considered separate.

\section{WORD $<$ \\ SIGNIFICATIO (impression) \\ NOMINATIO (object)}

The Abelardian distinction between nominatio and significatio makes all the difference, because here the meaning of a word is its object. The roles of representation and signification are switched. With this premise, general concepts take the place of universals, and semantics and meaning concern "words" (which Saussure would call mere signifiers that carry no meaning).

In Derrida's thinking, a similar development of ideas can be detected. When he substitutes the interpretant for the signified, he turns back towards phenomenological nominalism. The Peircean triad is lost in this procedure. For Derrida, there was no longer a real object, but merely the immediate object present in the mind. It was identified with the phenomenon. So, in the triad of semiosis, the Peircean "object" was transferred into the category of the representamen. The signified no longer existed either. Derrida's first interpretation had transformed the sign into a signifier, and the interpretant into the signified. His final conclusion, however, transferred the interpretant finally into the (original) area of the sign/representamen, the self-referential system of signs, because it was now considered the noematic meaning of the sign, not a lexical meaning common to all speakers using the linguistic system.

The main conclusion of this section is that Eco has visualized the graphic form of Frege's and Ogden and Richards's semantic theory erroneously. There was no triad, only a dualist "fork" emphasizing nominatio. The only benefit in Eco's explanation is that it enables scholars to detect a similar error in Derrida's critique toward the alleged logocentricism. Therefore, it is evident that both Derrida and Eco suggested a nominalistic, semantic interpretation for Peircean semiosis. For them, the interpretant became the conceptual content of the sign. Using Saussure's terminology, they stated that the interpretant was identical with the signified. Derrida and Eco use this new construction in their battle against the transcendental signified. This is why Derrida and Eco's semantic interpretation of Peircean semiotics is strained. Distorting Peirce's original ideas shifts the study of semiotics onto a postmodern path.

\section{Benveniste on Enunciation}

As we consider constructive alternatives, the work of Émile Benveniste (1902-1976) needs to be rehabilitated in contemporary scholarship. Being the great hero of young Ricoeur, Benveniste can be held up as the main writer to develop Saussure's semantics and should be placed beside Greimas, Jakobson and Lotman in the canon of semiotics scholars. Benveniste follows Saussure's main theoretical premises on the definition of the sign. This must be noted because he is sometimes known for his early article "The Nature of the Linguistic Sign" (1939) where he appears to oppose Saussure at certain points. What makes him special is that he shifts the focus from investigating the sign itself to the investigation of meaning and semantics in propositions. Here he brings up new terms such as discourse and enunciation. The first volume of his writings has been published in an English collection called Problems in General Linguistics.

Benveniste claims that when defining the sign-a unity of an acoustic image and concept-Saussure does not treat the relation of language to the real world, he does not question the latter's premises. Benveniste simply focuses on parole. This differs little from what Saussure himself had written. Therefore, Benveniste continues the project by presenting a theory of how language is able to signify in everyday life (Benveniste 1971, p. 46). 
In his "Form and Meaning in Language" ("La forme et le sens dans le langage") Benveniste seeks a general comprehension of the "very being of language". He says that the essence of language is to signify. By using language people give meaning to the world. "Language is the signifying activity par excellence." (Benveniste 1974, p. 217). Therefore, language is a bearer of signification. In the article "The Levels of Linguistic Analysis" Benveniste writes about meaning: "a certain property which this element possesses qua signifier: that of forming a unit which is distinctive, contrastive, delimited by other units, and identifiable for native speakers for whom this language is language" (Benveniste 1971, p. 108). Benveniste's first point of departure is similar to that of Saussure. He speaks of inherent meanings. In addition to this, however, human speech refers to the world of objects.

"But at the same time, all human speech has reference to the world of objects, both as a whole, in its complete utterances in the form of sentences, which refer to concrete and specific situations, and in the form of inferior units that relate to general and particular 'objects' recognized from experience or created by linguistic convention. Each utterance, and each term of the utterance, thus has a referend, a knowledge of which is implied by the native use of the language." (ibid.)

The special contribution that Benveniste brings to the Saussurean tradition is his emphasis on utterance. In Benveniste's writings we encounter two important concepts that explain his ideas, enunciation and discourse. Enunciation ("énonciation") is the act of producing an utterance ("énoncé"). He states that this means the "conversion of language into discourse" (Benveniste 1966, p. 254). In Saussurean terms, this means a change from langue to parole, the shift that Benveniste also calls the change from semiotics to semantics.

"What in general characterizes enunciation" he writes, "is the accentuation of the discursive relation to the partner". He calls it "the figurative framework of enunciation". There is a "structure of dialogue", as he says. "As discourse's form, enunciation posits two 'figures' that are equally necessary: one the source, the other the goal of the enunciation". For Benveniste, such a framework "is necessarily given with the definition of enunciation" (Benveniste 1974, p. 85).

Benveniste states that speaking, i.e., using language, involves addressing someone. This is why there is a significant difference between langue and parole: énoncé is a statement independent of context, but énonciation is bound and directed by the context. It is an act of stating. This makes language a "discursive instance". There is a difference between semiotics and semantics. Linguistic signs must be used. Discourse is the actual utilization of language. Utterance is a bearer of signification. It represents the medium through which man gives meaning to the world. This leads to Benveniste's great thesis: the essence of language is to signify. It is signification itself (Mosès 2001, p. 517).

When poststructuralism approaches questions of meaning from the point of view of langue alone, the language system, it misses the point. In this sphere, meaning in the traditional sense of the word disappears and a play between the autonomic binary elements of the linguistic system is introduced in its stead. According to Benveniste, however, meaning is a matter of discourse (parole). It is a matter of "semantics". The use of words takes place in enunciation, the act of producing an utterance. This is precisely where the speaker produces a conversion of langue into discourse-and this is where meaning is created.

\section{Web of Relations}

Such developments in the theory of signification produce useful results. In enunciation people speak about real objects (and events and all kinds of imaginable things). This is what a discourse is all about. It means that signification takes place in utterances. Benveniste speaks about evanescent signification and referential reality. One could also call this contextual meaning. In an utterance, words (in a strict sense precisely "words" now, not just linguistic signs) refer, indicate and represent. They are taken into a network of meaning. 
Their use depends on application and association, and concepts are put in a certain context. This is the reason why particular meaning in a sentence is evanescent. It focuses on one independent situation. Furthermore, this kind of "use" of words serves intentional speech. It is about communication. Benveniste speaks of dialogue. It concerns interaction and transmission of messages (Delorme 1998, p. 36). It is easy to see that much of what we today consider as the contemporary understanding of contextual meaning and rhetorical communication have their roots in Benveniste's writings.

Should we want to apply a triadic interpretation of Benveniste's theory-in order to explain the faults of Eco's application once more-this would result in a developed version of Saussure's semantics. In Benveniste's theory, in fact, we find a new triad that comes close to what Peirce has written about meaning, consisting of the bipartite sign that has a relation both to the object and an evanescent signification. Benveniste starts with the bipartite sign. The linguistic sign is only the first element in the dynamic process of signification. One must consider enunciation and discourse. In utterances meaning grows-but this does not alter the content of the code itself, the content of the linguistic signs of langue.

As noted, the original construction of theology-the soteriological statements now found in the New Testament-has been a matter of encoding. One of semiotics's main premises is that a sign is not simply a linguistic unit as such. A sign is about conditions and functions. A sign as a role is a manifestation of participation. For anything to serve as a sign entails participation in a web of relations, participation in a network of meanings, and adoption of a set of rules. This web of relations is where meaning is constructed.

Consider, for instance, how the meaning of Jesus's death is governed by a cultic discourse in the classical passage of 1 Cor 15:3-5. This early homology which is filled with expressions betraying an Aramaic original starts with a short passio Christi opening, contrasting a normal Greek work order, "Christ died". This description is not left hanging, though. The homology goes on saying: "Christ died for our sins (hyper tōn hamartiōn hēmōn) in accordance with the scriptures, and that he was buried, and that he was raised on the third day in accordance with the scriptures" (1 Cor 15:3-5; cf. the similar pattern behind Paul's baptismal theology in Rom 6:3-4; for the analysis of 1 Cor. 15, see Hurtado (2005, pp. 168-70)). There are several factors here that form the web of relations investing the opening statement with meaning. First, the implied narrative restores the intention of Old Testament sacrificial laws. Second, the focus is on a substitutional sacrifice (hyper). And third, according to the first apostles, Jesus's death should be interpreted as a vicarious act for the transgressions of Israel.

In such passages there are apparently elements that resist the free selection of codeand simultaneously reduce the possibilities and alternatives to interpret this homology. The key question in biblical hermeneutics will now be: what are these elements of resistance?

\section{The Theory of Discursive Resistance}

New solutions require new premises. Saussure spoke of syntagmatic and associative relations. It is necessary to adapt these concepts into a wider hermeneutical discussion. Associative relations concern the networks into which words are taken in utterances. As Peirce has noted, such links create new impressions that depend on different kinds of contexts. For meaning, many formal factors are important, such as lexical meaning (language system), grammar (intrasystemic relations), syntagmatic relations close to the expression (similarities and opposites), semantic fields, and style (legal, hortatory, etc.). In addition to these we encounter factors that directly deal with other syntagmatic and associative relations.

Idiomatic speech also belongs to these factors. It is important to pay attention to linguistic conventions of the speech community. Idioms are only one example of conventional factors that direct semiosis. We must also be alert to intertextual relations and metanarratives. Of these two, intertextual relations are the easier ones to handle, especially in cases where one can detect quotations or clear allusions. Metanarratives, however, open up a field of their own. 
How should one understand the crucial theoretical concept "discursive resistance"? The term concerns semantics. The linguistic phenomenon of idioms, therefore, provides an analogue for what I would like to call the hermeneutics of "discursive resistance". We can refer here again to Saussure's notion: "These idiomatic twists cannot be improvised; they are furnished by tradition". Since meaning proper is constructed in sentences, scholars from Saussure and Jakobson onward have stated that, in the process of encoding, there are linguistic "rules" that govern the process. In the production of an utterance there are linguistic elements that resist the free selection of components. As noted, idioms no doubt serve as such factors, and so do cultural conventions. The main thesis of the present article is that when we adapt the same principle to the interpretation of metanarratives the result is quite similar. We cannot speak of linguistic resistance in the strict sense because this is not a matter of langue but of parole - using Saussure's terminology. Therefore, it is better to speak of discursive resistance. The conclusion, to state it as precisely as possible, is that a metanarrative can control the construction of a crucial theological statement, and traits of this can be found in the New Testament. This is why it is not hermeneutically legitimate to interpret theological statements without exploring the nature of the metanarratives involved.

As we consider metanarratives, their influence in the process of constructing meaning is important. They direct the semiotic process in utterances as implied narratives, among other things. It is noteworthy that they appear to function, theoretically, in the same way as idioms. Their use resists the free selection of components in encoding. Therefore, they are extreme examples of conventional meaning. They also become a means of appropriation: the construction of the sentence is not spontaneous but constrained. One faces a movement from optional to compulsory. When for instance the metanarrative of enthronement directs the construction of a Christological statement, the basic theme dominates the process and becomes compelling for the ancient author. In many cases, an Old Testament passage-an intertextual element-completes the process.

Metaphors, in turn, appear to have a special role in the construction of New Testament theology because they serve as signs in semiosis. Most soteriological and Christological presentations are completely dressed in metaphorical language. Metaphors provide authors with a means for speaking about metaphysical issues, about God's reality. This is, for example, how Koester has applied the theory to gospel studies (Koester 2003, 4f.). Metaphors, therefore, become part of the hermeneutics of discursive resistance. By using metaphors, semiosis in a way locks up the signification process. Metaphors can be freely selected but, once in a text, it cannot be changed into some other image. Instead, it all needs to be understood in terms of hermeneutics of utterance.

What happens when a disciple, apostle, or Jesus' follower gives a theological interpretation of something the Lord does? The construction of an original theological statement-in the early Christian community-is parallel to the construction of a historical description. Some particular event is provided with meaning, it is put into a context, and it is considered significant. In history writing, or creating a short gospel story, the process can be called metahistory. It means a narrative approach to history. Historical narratives are not lists of details but presentations of alleged causalities and meanings. Even these narratives are not devoid of theological meaning.

In theology proper, for instance in Christology, such a process can be called metatheology. The meaning of an event-expressed in utterances-is usually a product of a multidimensional network of ideas, coming from Old Testament texts, prophetic proclamation, Jewish tradition, temple ideology and Jesus' own teaching. This is semiosis. New signs are born in the process where particular theological topoi and motifs are applied to interpret the meaning of historical events, often the "stations" of Jesus' via crucis and the empty tomb (like above in 1 Cor. 15). Does one impose a theological structure on the events he or she interprets? The setting is different from that of constructing metahistory.

In metatheology, the multidimensional network definitely invests natural events with meaning. In a sense this is a procedure that implies imposition. But what could serve 
as a "structure" that would be clear enough to justify the hermeneutical inference made by the author? There must be a tradition history or religious cultic point of reference on which semiosis can build. But like in the application of a metaphor, the tenor must not be overshadowed or displaced by the vehicle. Metanarratives no doubt have a primary role here. They are implied in a statement, as was the case in one of our examples where the enthronement act was applied to Jesus' resurrection. Metanarrative guides the new interpretation, for example the belief that after Easter, Jesus the Son of David is a heavenly king who has been invested with eschatological power and dominion.

One of the main postulations in this paper will be that a proper definition both of the linguistic sign and the process of signification leads to a useful hermeneutics on which a New Testament theology can be built.

\section{Jubilee and Liberation from Egyptian Slavery in Theological Semiosis}

How can a metanarrative control and guide the construction of theological statements in the New Testament? What kind of discursive resistance can we decipher in the essential theological descriptions that can be considered basic for the entirety of New Testament theology? The basic claim of this essay is that since narrative is an epistemological factor, several soteriological and Christological presentations revolve around certain topoi (such as metaphors), motifs (recurring topoi) and themes which together provide materials for both simple narratives and large metanarratives. This means that when the reader wishes to explicate the theological content of a particular passage, it will be most useful to focus on the dynamics between descriptions and the narratives they rely on.

A perfect example of such a dynamical relationship between different descriptions and overarching metanarratives is theology concerning an eschatological jubilee, the day of the final restoration of Israel. Liberation and abolition are recurring themes both in Old Testament and in New Testament theology. Furthermore, the narrative of exile and restoration has always been connected with the arrival of an eschatological jubilee (C. J. H. Wright 1992, p. 1025). This issue opens up a hermeneutical horizon where an even more extensive metanarrative can be constructed: the deliverance from slavery. This is a metanarrative that unites exodus theology and the end of the exile. One of the uniting factors is the fact of slavery. Egypt itself, in the writings of the Old Testament, is the "house of slavery," (Ex. 13:3). In several passages, however, Egypt and Babylon are no longer separated from each other. In the latter case, however, the slavery starts to mean more a slavery under sin.

Therefore, the first prominent Old Testament narrative creating the identity of the people of Israel is the one rejoicing over an extraordinary historical event: release from Egypt. It is closely linked with the theme of jubilee-but this element needs some background. Even though the narrative concerning the arrival of the year of freedom, or jubilee, is directed to the future, its foundation lies in the past. Exodus itself is a story of deliverance, and pesach is the festival of liberation. Therefore, in Leviticus 25-27, a jubilee becomes the feast symbolizing abolition and the freedom from slavery. It also has many social consequences. Slaves must be set free after seven sabbatical years (49 years; Lev. 25; in this context concerning Jewish slaves) and so the land too will be given a rest (Bergsma 2007, 81f.).

"And you shall hallow the fiftieth year and you shall proclaim liberty throughout the land to all its inhabitants. It shall be a jubilee for you: you shall return, every one of you, to your property and every one of you to your family." (Lev. 25:10)

These chapters in Leviticus have become statutes of social justice. Furthermore, the ideas of release and even reconciliation have a theological foundation. Our possessions are merely on loan from God himself. They will be returned when the time comes. According to Leviticus, land "shall not be sold in perpetuity" (25:23). This results in the great commission that land shall be released in the jubilee $(25: 28,31)$. The Torah teaches that Israelites are but the temporary guardians of God's property. The Israelites must not be enslaved to money and property more than to the Lord. Mammon, already in Jewish texts, is an idol, a false god (C. J. H. Wright 1992, p. 1026). 
In the writings of the prophets, then, the word for jubilee is changed into "the year of liberty" (drwr). There may be several reasons for this, but in Leviticus 25 it is already the year when liberty is proclaimed. Meaning grows, and the jubilee becomes an interpretant in a new interpretation. It is easy to see why such a symbol of liberty became crucial in exile as a symbol for returning from captivity. This allows for a fresh treatment of the feast of jubilee and the liberation theme both in Old and New Testament texts. Descriptions build on the confession "God who brought us back from Egypt". It is one of the main symbols for the Mosaic covenant.

In the narrative itself there are several unitive features. They can be found directly in Lev. 25-27, in the passages that describe the year of jubilee. Jubilee and deliverance from slavery belong together. The significant theological conclusion in the Israelite exodusidealism concerns the ending of slavery. The event of exodus itself reflects being freed from the power of oppressive pharaohs and forced labor in Egypt. The ending of slavery further results in a new morality: no one should be enslaved (Lev. 25:39-42). This theology gives the jubilee its hermeneutical power. Jubilee is a feast of abolition, and the paradigmatic example for this is Egypt. The same argument is repeated in chapter 26. "I am the Lord your God who brought you out of the land of Egypt, to be their slaves no more; I have broken the bars of your yoke and made you walk erect." (Lev. 26:13).

It is quite easy to detect a process of signification, semiosis, in these texts. There are also good grounds for understanding the growth of meaning and a new interpretation because, in Old Testament theology, Egypt and Babylon play a similar role. The days of slavery return as Israel is taken into Babylonian exile. The unity of these two is established already in Leviticus 26. First the prophetic proclamation states that in case of apostasy, God will set his "face against you" (26:17). Should this continue more severe consequences will follow: "If you continue hostile to me, and will not obey me, I will continue to plague you sevenfold for your sins." (26:21). A new slavery will take place. "I will bring the sword against you, executing vengeance for the covenant; and if you withdraw within your cities, I will send pestilence among you, and you shall be delivered into enemy hands." (26:25).

"And you I will scatter among the nations, and I will unsheathe the sword against you; your land shall be a desolation, and your cities a waste. Then the land shall enjoy its sabbath years as long as it lies desolate, while you are in the land of your enemies; then the land shall rest, and enjoy its sabbath years." (Lev. 26:33-34)

Finally, the theme grows into an eschatological proclamation about the restoration of Israel. In the second part of the book of Isaiah, the hope of restoration is based on the arrival of an eschatological jubilee, the year of freedom. Restoration is described in terms of redemption already in Isa. 52:7, in the passage that speaks of the restoration of God's kingship. A little later, in the paradigmatic passage in 61, liberty is promised: "he has sent me to bring good news to the oppressed, to bind up the brokenhearted, to proclaim liberty to the captives, and release to the prisoners". This day of restoration can be identified as the final jubilee: "to proclaim the year of the Lord's favor, and the day of vengeance of our God; to comfort all who mourn." (Isa. 61:1-2).

Exodus' rhetoric on slavery forms the basis for the new interpretation. The task of Lord's servant is to "proclaim release to the prisoners." This is a theology of abolition. Liberty to the "prisoners" concerns all those who have lived under God's punishment in the exile. And almost like underscoring the exodus motif in restoration eschatology, the day of salvation is identified as the year of the Lord's favor, the jubilee. A similar interpretation can be found later in Jubilees 50, as well as in 11QMelch. II.4-5 (Bergsma, Jubilee, 238).

The narrative tradition both of the Old Testament and Second Temple Jewish theology is quite clear on the issue. This serves as the intertextual background for New Testament descriptions where restoration and abolition are recurrent themes. Considering the particular topoi and themes accompanying the metanarratives, it is obvious that Jesus's teaching against mammon, his proclamation concerning Israel's punishment, the constant focus on slavery, and the great gospel of abolition belong together. These features are inevitably 
linked with Jesus's teaching about the new brotherhood and probably even Paul's idea of the congregation as the body of Christ.

There are two particular passages in the New Testament where restoration is depicted precisely as the arrival of the jubilee. At Nazareth Jesus gives a sermon on Isa. 61, the passage proclaiming the mission of the Anointed One: "to bring good news to the oppressed, to bind up the brokenhearted, to proclaim liberty to the captives, and release to the prisoners; to proclaim the year of the Lord's favor" (Isa. 61:1-2). The short comment on the content emphasizes the actuality of restoration: "Today this scripture has been fulfilled in your hearing." Symbols grow. According to this actualizing interpretation Jesus brings the eschatological jubilee into being.

The slavery mentioned by Jesus is often slavery under sin: "everyone who commits $\sin$ is a slave to sin." (John 8:34). Jesus is not speaking merely of the exile itself but of the exilic condition and the reason for the punishment. As the great prophets proclaimed, the reason for the deportation is Israel's sin. Therefore, the way back, the "highway" John speaks about, starts with repentance. A similar rhetorical device is also adopted in the Pauline tradition (Gal. 4:7-9; Titus 3:3).

Furthermore, in Matthew 11:5, in Jesus's answer to John's disciples, we find an eschatological catena, a combination of quotations from Isa. 26, 29, 35, and 61. The time of restoration is not only the time of abolition but also a kairos for the entire renewal of creation: "The blind receive their sight, the lame walk, the lepers are cleansed, the deaf hear, the dead are raised, and the poor have good news brought to them." In the renewal of Israel the cultic uncleanness will be sanctified by God's own initiative. The eschatological nature of the passage became clear after the publication of 4Q521 where restoration theology like "freeing prisoners" is linked with making "the dead alive." Slavery is understood in the broadest possible sense. Paul clearly understands this when he writes that, in Christ, the tyranny of death is conquered (Rom. 5:14-17; 1 Cor. 15:21-22; Gal. 2:19-20).

In New Testament Christology, Christ inaugurates the new exodus-restoration: the new Moses (Acts 3:22), the Savior/sōtêr (John 4:42; Acts 13:23) and the Creator himself (John 1:3; Col. 1:16). The importance of these features is highlighted as we recall that, in general, restoration theology in the New Testament is depicted as the entrance and enthronement of the Son of David. The re-enactment of the divine enthronement expresses the fulfillment of the Isaianic besorah, "Your God reigns." There is connection between resurrection and eschatological enthronement (Eskola 2001, 217f.).

As regards Paul's theology, its essence can be seen in the "summary of summaries"- as it has been called —of the Letter to the Romans. As a conclusion of his entire train of thought, and right before the last doxology, Paul writes: "God has imprisoned all in disobedience so that he may be merciful to all" (Rom. 11:32). Both here and in Galatians, salvation is depicted in terms of imprisonment and release. "But the scripture has imprisoned all things under the power of sin, so that what was promised through faith in Jesus Christ might be given to those who believe." (Gal. 3:22). Jubilee and abolition have significant value in the metanarratives that Paul relies on when constructing his soteriology.

Furthermore, abolition is the main theme in Galatians 4. As Wright has noted, Paul speaks here of "slavery" under the elements of the world. Compared with the "complex webs of allusion and echo" in Second Temple Jewish literature, as Wright says, Paul's description is a true exodus-story. He employs several features of the exodus-narrative and makes them serve restoration eschatology, promising liberation (Wright 2013, p. 656; cf. N. T. Wright 1992, p. 268).

There are also some interesting interpretants in New Testament texts that bring some of the themes of Old Testament theology to a new level. In the beginning of Jesus's work, John the Baptist became an interpretant for the end of the exile. Toward the end of Jesus' earthly work, we find another example. Outside Jerusalem, the colt that becomes his royal charger is an interpretant for liberation and the arrival of the new David to Zion (Zech. 9:9). In this eschatological performance no words are needed: the interpretant itself is enough in mediating the message to the hearers (Mark 11:1-11). 
As we investigate the growth of meaning and ask how the interpretation of the narratives of liberation from Egyptian slavery and eschatological jubilee have developed, it becomes clear that these themes are significant both in Old Testament theology and New Testament teaching. In the Old Testament, liberation from Egyptian slavery was an essential confessional and theological theme, and it formulated the identity of the Israelite community. This was later expanded into exilic theology, and the jubilee, the year of release, became a leading motif that could be used when expressing the eschatological hope of the people. On this foundation the narrative of abolition was constructed.

In the New Testament, restoration eschatology has a primary role in Jesus's proclamation. Israel still lives in spiritual exile: deported and scattered among nations. Jesus as the Son of Man brings restoration into view and summons the eschatological jubilee that aims at a final abolition of enslaved humanity (Eskola 2015, p. 118). Exodus and the promised land have become metaphors first for the "release of prisoners" of the Babylonian (and Assyrian) exile, and second for the great release of all the prisoners of sin and death.

\section{Conclusions: Signification Theory and the Future of New Testament Theology}

According to the main thesis of the present essay, semiotics of the linguistic sign enables one to tackle some essential questions of biblical hermeneutics. Great theoretical problems are simpler than first thought, and they can be reduced to different views concerning the nature of the sign, the nature of words. Signification, as Benveniste has proved, is a matter of enunciation. Saussure - when understood correctly-ended the era of nominalism despite the fact that phenomenological tradition attempted to prolong its final dethronement.

There are several discursive factors that influence the construction of meaning in sentences. When New Testament scholars wish to explicate the content of the texts, they need to deal with narratives and metanarratives, often supplemented by influential metaphors presenting Christ, for instance, as a king, priest, or slave. It is quite common to refer to such elements as "titles" but, from the perspective of constructing theology, they are details that betray the presence of discursive resistance. The process of encoding has not been free but directed by particular narrative factors.

What are the prospects, then, for the future of New Testament theology? How does a semiotic approach improve this field of study? Firstly, it is easier to assess earlier approaches to the study of the texts. There is no hidden meaning behind the utterances that we deal with, no universal truths (Strauss), no ethical agenda (Harnack), no existential experience (Bultmann), and no deconstructed inversion on which a scholar should build. Instead, there are compelling factors in the text that direct the act of decoding.

Secondly, it is easier for scholars to make a distinction between textual and linguistic approaches on the one hand, and ideological criticism and reader-response on the other hand. The latter deals with issues of reception and assessing meaningfulness. In the academic world today there is no doubt room for an alternative to deconstruction, to subjective reading, to ideological criticism. The theoretical conclusion merely states that these are not examples of New Testament theology. Instead, they are examples, for instance, of philosophy of religion or results of an ideological history-of-religion reading that has gained popularity in recent years.

Thirdly, a better understanding of processes of signification will help scholars to focus on relevant issues. In the context of communication theory, the tenets and intention of the original author will return because encoding is a means for enunciation. Hermeneutics proper depends on a strict definition of the linguistic sign. As meaning is actually constructed in utterances and can be seen as a result of encoding, it has a special character. Meaning when created is evanescent and contextual, directed by many elements that resist the free selection of the code. Therefore, constructing a New Testament theology is a hermeneutical task of decoding.

The theory of discursive resistance is one alternative for a fresh approach since Saussure's linguistic turn. A proper reading of Saussure and Benveniste enables us to make 
essential corrections to the understanding both of semiotics and New Testament theology and, simultaneously, to the theory of meaning.

Funding: This research received no external funding.

Institutional Review Board Statement: Not applicable.

Informed Consent Statement: Not applicable.

Data Availability Statement: Not applicable.

Conflicts of Interest: Neither the manuscript nor any parts of its content are currently under consideration or published in another journal. The author declares no conflict of interest. The author also follows the ethical policies of the journal.

\section{References}

Benveniste, Émile. 1966. Problèmes de linguistique générale I. Paris: Gallimard.

Benveniste, Émile. 1971. Problems in General Linguistics. Miami: University of Miami Press.

Benveniste, Émile. 1974. Problèmes de linguistique générale II. Paris: Gallimard.

Bergsma, John S. 2007. The Jubilee from Leviticus to Qumran: A History of Interpretation. VT.S. 115. Leiden: Brill.

de Saussure, Ferdinand. 1983. Course in General Linguistics. London: Duckworth.

Delorme, Jean. 1998. Orientations of a Literary Semiotics Questioned by the Bible. Semeia 81: 27-61.

Derrida, Jacques. 1973. Speech and Phenomena. And Other Essays on Husserl's Theory of Signs. Evanston: Northwestern University Press.

Derrida, Jacques. 1982. Margins of Philosophy. Brighton: Harvester.

Derrida, Jacques. 1997. Of Grammatology, Corrected ed. Baltimore and London: Johns Hopkins University Press.

Eco, Umberto. 1976. A Theory of Semiotics. Critical Social Studies. Thetford: Indiana University Press.

Eskola, Timo. 2001. Messiah and the Throne: Jewish Merkabah Mysticism and Early Christian Exaltation Discourse. WUNT 2. Reihe 142. Tübingen: Mohr/Siebeck.

Eskola, Timo. 2015. A Narrative Theology of the New Testament: Exploring the Metanarrative of Exile and Restoration. WUNT 350. Tübingen: Mohr/Siebeck.

Eskola, Timo. 2021. New Testament Semiotics: Linguistic Signs, the Process of Signification, and the Hermeneutics of Discursive Resistance. BINS 193. Leiden: Brill.

Greenlee, Douglas. 1973. Peirce's Concept of Sign. Approaches to Semiotics 5. The Hague and Paris: Mouton.

Hervey, Sandor. 1982. Semiotic Perspectives. London: Allen \& Unwin.

Hurtado, Larry. 2005. Lord Jesus Christ: Devotion to Jesus in Earliest Christianity. Grand Rapids: Eerdmans.

Koester, Craig. 2003. Symbolism in the Fourth Gospel: Meaning, Mystery, Community. Minneapolis: Fortress.

Liszka, James J. 1996. A General Introduction to the Semeiotic of Charles Sanders Peirce. Bloomington and Indianapolis: Indiana University Press.

Mosès, Stéphane. 2001. Émile Benveniste and the Linguistics of Dialogue. Revue de Métaphysique et de Morale 32: 509-25. [CrossRef]

Ogden, Charles Kay, and Ivor Armstrong Richards. 1966. The Meaning of Meaning: A Study of the Influence of Language upon Thought and of the Science of Symbolism, 10th ed. London: Routledge.

Pharies, David A. 1985. Charles S. Peirce and the Linguistic Sign. Foundations of Semiotics 9. Amsterdam: Benjamins.

Raschke, Carl A. 1979. The Alchemy of the Word. Language and the End of Theology. AARSR 20. Missoula: Scholars.

Sebeok, Thomas A. 2001. Signs: An Introduction to Semiotics, 2nd ed. Toronto Studies in Semiotics and Communication. Toronto: University of Toronto Press.

Tobin, Yishai. 1990. Semiotics and Linguistics. London: Longman.

Wright, Christopher J. H. 1992. Jubilee, Year of. ABD III: 1025-30.

Wright, N. Thomas. 1992. Jesus and the Victory of God. Christian Origins and the Question of God 2. Minneapolis: Fortress.

Wright, N. Thomas. 2013. Paul and the Faithfulness of God I-IV. Christian Origins and the Question of God 4. Minneapolis: Fortress. 